\title{
SYMPOSIUM ON AFRICA AND THE FUTURE OF INTERNATIONAL TRADE REGIMES
}

\section{DEFINING AND REDEFINING U.S.-AFRICA TRADE RELATIONS DURING THE TRUMP PRESIDENCY}

\author{
Stephen Lande* and Dennis Matanda ${ }^{*}$
}

In an era in which multilateral trade arrangements have garnered more public notoriety than ever before, the suboptimal trade and investment relationship between America and Africa, as underpinned by the African Growth and Opportunity Act (AGOA), is one of the less controversial ones. AGOA could nevertheless use some adjustments or augmentations to facilitate deeper U.S.-Africa commercial relations. For instance, adjusting AGOA's origin rules could nudge the private sector on both sides of the Atlantic towards gains for U.S. and African employment and the reduction of trade deficits. Africa must leverage the period before AGOA expires to redefine its trade relationship with the United States in innovative ways. The United States should welcome these measures, since the type of value that Africa would add to the global supply chain would not replace the high-quality jobs that the Trump Administration would like to see in the United States. In fact, this type of production would make U.S. manufacturing more competitive.

\section{Missed Opportunities in $A G O A$}

In the spring of 2015 — at the height of a concerted multistakeholder effort to update and renew AGOAErastus J. Mwencha visited Capitol Hill. The then-Deputy Chairperson of the African Union genially reminded his House and Senate audiences that, in a bid to transform America's flagship economic program for Africa, AGOA's beneficiaries had made a series of substantive suggestions to the bill Congress was considering. But at both House and Senate venues, Mwencha learned that the very factors that had crippled the original AGOA enactment process - an overdependence on tariff reduction; the inherent limitations of one-way-non-negotiated trade preferences; and basic legislative limitations-appeared to persist fifteen years later. ${ }^{1}$ As a result, while Congress overwhelmingly voted for the Trade Preferences Extension Act, the AGOA Extension and Enhancement Act component contained only limited changes: a ten-year extension of the law, to 2025; slight adjustments to origin rules; and more onerous eligibility requirements. ${ }^{2}$ Missing from the updated AGOA program were two key aspects

* Stephen Lande runs Manchester Trade, a Washington, D.C.-based international advisory. He previously served as a diplomat at the U.S. State Department and as an Assistant United States Trade Representative in the Executive Office of the President.

+ Dennis Matanda is the Head of Government Relations at Manchester Trade and Editor of The Habari Network. He also works on projects for US AID, the African Union, COMESA, and various African governments.

${ }^{1}$ Ryan McCormick, The African Growth and Opportunity Act: The Perils of Pursuing African Development Through U.S. Trade Law, 41 TEx. INT'L L.J. 339 (2006) (suggesting that one reason that Congress watered down AGOA was that the pro-African constituency had not meaningfully countered protectionist arguments for saving American jobs).

2 Trade Preferences Extension Act of 2015, 114 Pub. L. No. 27, 129 Stat. 362 (2015).

The American Society of International Law and Stephen Lande and Dennis Matanda (C 2017. This is an Open Access article, distributed under the terms of the Creative Commons Attribution licence (http://creativecommons.org/licenses/by/4.0/), which permits unrestricted re-use, distribution, and reproduction in any medium, provided the original work is properly cited. 
Mwencha specifically requested: providing restricted African cash crops with AGOA privileges, and amending origin rules to encourage regional and global value chains in Africa.

\section{The Rise of China in Africa}

Although Reuben Brigety, former U.S. Ambassador to the African Union, has argued that the relationship between the United States and Africa has "blossomed," China passed the United States as Africa's largest trade partner in 2009. Today, Africa looks to China to stimulate the continent's growth. ${ }^{3}$ According to the China Africa Research Initiative, Chinese loans to all fifty-five African countries increased from US\$121 million in 2000 to over US $\$ 17$ billion in 2017.4 Pursuing an investment-heavy model when Chinese exports increased after China joined the World Trade Organization (WTO) in 2000, ${ }^{5}$ then-Chinese Premier Zhu Rongji oversaw a surge of Chinese investments in Africa from zero in 2000 to about US\$3.1 billion in 2014. As Leslie Gelb observed, Africa's fear of American military might was eclipsed in 2010 by an existential fear of China's ability to give or withhold trade and investment. ${ }^{6}$ China's billion dollar investments in infrastructure, medical facilities, and even sports stadiums severely dwarf the multi-million-dollar development compacts the United States grants to African countries making progress in governance and service delivery under the Millennium Challenge Corporation. And while overall exports from sub-Saharan Africa to the United States increased from about US $\$ 20$ billion in 2000 to a high of US $\$ 82$ billion in 2008, China's exports to Africa were approximately US $\$ 103$ billion in 2015 , with China importing US $\$ 69$ billion worth of African products. ${ }^{7}$ By 2016 , Africa's exports to America were US $\$ 20$ billion; American exports to Africa were US\$12 billion, and as of March 2017, AGOA exports were worth only US $\$ 2.3$ billion. ${ }^{8}$

While the United States was the first non-African country to establish a diplomatic mission dedicated exclusively to the African Union, ${ }^{9}$ China's successes may make the task of realigning, defining, and redefining trade policy the least of America's quandaries in Africa. Essentially, this type of economic disengagement leaves the world's largest single economy ill-prepared for a scenario in which rising powers like China rapidly position themselves to exploit the wealth that lies within Africa's borders. ${ }^{10}$ For example, where China has provided loans to Africa, African governments have become even more skeptical of International Monetary Fund and World Bank arrangements that may be tied to American ideals and democratic governance. ${ }^{11}$ Illustratively, having proclaimed in October 2017 that China's Xi Jinping was "the world's most powerful man," The Economist painted a bleak outlook for the America/Africa dynamic, suggesting that President Donald Trump is lessening America's influence abroad because he scorns the values and alliances that underpin this intangible asset.

\footnotetext{
${ }^{3}$ United Nations Econ. Comm'n for Africa, Urbanization \& Industrialization for Africa's Transformation: Economic Report on Africa 201753 (2017).

${ }^{4}$ See Data: Chinese Loans to Africa, China Africa Research Initiative.

${ }^{5}$ David Dollar, China's Engagement with Africa: From Natural Resources to Human Resources 13-19 (China Center at Brookings, 2016).

${ }^{6}$ See Heather Long, China Is Crushing the U.S. in "Economic Warfare", CNN (June 30, 2016).

7 See Data: China-Africa Trade, China Africa Research Initiative.

8 See AGOA.INFO.

${ }^{9}$ Reuben Brigety, Trump's Deafening Silence on Africa, Foreign PoL'y (Feb. 15, 2017).

10 See Robert Blackwill \& Jennifer Harris, War by Other Means (2016).

11 Garth le Pere \& Garth Shelton, China, Africa South-Africa: South-South Co-Operation in a Global Era (2007).
} 


\section{What Africa Could Do in the Short-Term}

In addition to encouraging AGOA beneficiaries to collectively generate export promotion strategies that leverage regional integration and global value chains, African countries should marshal the resources to obtain from the U.S. Congress and the U.S. private sector the kind of AGOA Mwencha came to promote in the first place. Africa should highlight two arguments. First, American investment played a statistically significant role in propelling the remarkable growth in Asia forward and could do the same for Africa. Second, as the Brookings Institution and the UN Economic Commission for Africa (UNECA) have argued, making modest changes to a few AGOA provisions should make the program more effective and present beneficiaries with a viable way to diversify trade, build capacity, and integrate their economies into higher rungs of global value chains for value-added products in the short-term—at least, before 2025.

In their groundbreaking AGOA scenarios, Brookings/UNECA observed that some degree of reciprocal trade between the United States and Africa would be beneficial for African exports if U.S.-Africa trade were accompanied by deeper regional integration within the continent. ${ }^{12}$ From this perspective, timing matters. To avoid the types of concerns that arose about the EU's Economic Partnership Agreements, sequencing is crucial: integration first, followed by agreements with third countries. Thus, America's current inability to proactively adjust its Africa policy should not prevent Africa's fifty-five sovereign nations, or its regional economic communities, from initiating changes to the status quo. Such efforts should emphasize avoiding the consequences of premature deindustrialization. ${ }^{13}$ Aside from adopting various strategies to fully utilize AGOA's market access provisions before these expire in 2025, AGOA beneficiaries should collaborate with non-AGOA beneficiaries to holistically eschew any negotiation of partial reciprocal agreements with major powers until a fully-functional Continental Free Trade Area (CFTA) currently under negotiation is in place.

Fortunately, with AGOA now in place through 2025, there is no reason for Africa to seriously consider a more reciprocal agreement until the end of President Trump's current term. This will allow time for Africa not only to complete the CFTA in the next year or two but also to establish the basis for a common external tariff. Once a common external tariff is in place, Africa can negotiate from a common platform and thus avoid the need for complex origin rules that slow the movement of goods across borders, thus undermining the worthy objectives of trade facilitation efforts.

In fact, there are dangers to proceeding prematurely. The Trump Administration promises to impose more stringent requirements for trade partners than previous administrations demanded in their gold-plated agreements. The demand for a gold-plated free trade agreement (FTA) led to the failure to negotiate the only FTA ever tried between the United States and a sub-Saharan Africa country (the South Africa Customs Union-U.S. FTA). Further, the United States has not been willing to allow developing countries to enter nontraditional markets. The new model is demanding less use of third-country content and minimal U.S. content in origin rules. Of particular concern to Africa should be the Administration's efforts within the North American Free Trade Agreement negotiations to reduce the use of third-country fabric in the manufacture of eligible clothing, which, if carried over to Africa, would gut the third-country-fabric provision— the most significant provision in the current AGOA program.

\footnotetext{
${ }^{12}$ Simon Mevel et al., The African Growth and Opporunity Act: An Empirical Analysis of the Possibilities Post-2015 (Africa Growth Initiative at Brookings \& United Nations Economic Commission for Africa, July 2013).

${ }^{13}$ Dani Rodrik, Premature Deindustrialization, 21 J Econ. Growth, 1 (2016). See also Dani Rodrik, Is Liberal Democracy Feasible in Developing Countries?, 51 STUd. Comp. INT'L Dev. 50 (2016).
} 


\section{An Ideal American Trade Initiative for Africa?}

Although AGOA allows duty-free and largely quota-free (DFQF) market access to the U.S. market for as many as 1,835 beneficiary products in addition to the over 4,600 GSP products, tariffs on products excluded from AGOA - especially on agricultural goods - remain high. As Brookings and UNECA show in the 2013 baseline scenarios, while AGOA benefits cover 97.5 percent of Africa's exports, extending DFQF benefits to all Africa's exports would stimulate the continent's exports by over US $\$ 105$ million. ${ }^{14}$ Thus, an American Trade Initiative for Africa ought to challenge traditional trade tools such as tariff rate quotas (TRQs). For their part, African states should make the case for the sort of AGOA origin rules that encourage production of African intermediary goods for American supply chains, effectively inserting Africa even faster into global value chains.

While the argument for adjusting AGOA origin rules is more obvious, the one for challenging TRQs is not. However, the journey to granting DFQF access for the balance of 2.5 percent most sensitive products to the United States would have to start with changes to America's archaic trade regime. Like most member countries of the Organization for Economic Co-operation and Development, the United States protects some of its agricultural subsectors by putting forty-six TRQs on seven groups of agricultural commodities-with sugar and dairy accounting for two-thirds of the TRQs. Simply put, the TRQs on sugar, cotton, peanuts, sweetened cocoa, and leaf tobacco, among other products, are, at their root, tools designed to protect the American producer by ensuring that trade patterns are not distorted.

\section{Working with the Trump Administration}

To surmount the TRQ challenge, it is important to highlight that the Obama Administration suffered neither serious political nor economic consequence for designating upland cotton for duty-free access for four West African least-developed countries (LDCs) in 2015. ${ }^{15}$ Hence, an African advocacy campaign aimed at the Trump White House must emphasize that the United States could take the same steps for those African cash crops currently subject to the archaic TRQs. Unlike in other areas of trade policy, President Trump has sufficient power to unilaterally include Africa's groundnuts, sweetened cocoa, cotton, tobacco, and sugar in the special tariff treatment category. Even if tariffs are not reduced to zero, a competitive tariff such as the 6 percent tariff given to Brazilian imports would increase exports from Zambia, Tanzania, Mozambique, Ivory Coast, Ghana, Nigeria, and Namibia, among other countries that do not fully exploit AGOA benefits.

A push to update AGOA origin rules could have the dual benefits of (i) generating competitively-priced finished goods from any American chains that utilize cheaper African inputs, and (ii) inserting Africa further into global manufacturing. Because Africa is not home to the sorts of jobs President Trump wants to keep in or attract to America, an AGOA origin update could allow the Trump Administration to bolster an American manufacturing resurgence.

Hypothetically, U.S.-Africa trade and investment policy could receive a significant boost if President Trump and the Republican-led Congress emulated the positive impact that AGOA's third-country-fabric provision had on Africa's export promotion. Adjusting AGOA's origin rules for textiles allowed apparel/clothing retailers such as Gap and Banana Republic to import cheaper goods from Africa because manufacturers were no longer as restricted in where they sourced apparel inputs. An African country such as Lesotho would import textiles

\footnotetext{
${ }^{14}$ See Mevel et al., supra note 12.

15 See New U.S. Initiatives to Boost Trade and Investment Opportunities for Least Developed Countries, OfFiCE OF THE UNITED STATES Trade Representative.
} 
from Taiwan or Vietnam and have African seamstresses stitch shirts, pants, and dresses for Gap. This apparel would qualify for AGOA's DFQF provisions under special rules for garments not applicable to other products.

Using third-country-fabric provisions as a model, the United States could extend the same benefits to either intermediate or finished products within the light manufacturing space. This could be achieved by ensuring that the AGOA origin rule recognizes that world class supply chains may assemble and otherwise produce intermediate components in poorer countries - with final assembly taking place elsewhere before being shipped to the United States. Since supply chains keep detailed verifiable records of the value of each country's added value, the United States could allow supply chains to claim duty reductions on third-country imports containing identifiable components from AGOA beneficiaries, even if products are finished outside Africa. Second, one could ease the stringent requirement that AGOA benefits be granted only to products where at least 35 percent of direct processing costs are incurred in Africa. Because most African input occurs, for the moment, via low-cost assembly, the 35 to 50 percent threshold is hard for any assembled product to meet. However, a reduction in origin rule requirements should lead to more supply chains moving light manufacturing away from Asia to Africa-translating into an increase in Africa's value added/supply chain activity.

Incidentally, an American Trade Initiative for Africa should neither operate in isolation, nor only leverage traditional trade tools. This initiative should take full advantage, for instance, of the sheer number of successful business people assembled in Trump's cabinet. With entities such as the Corporate Council on Africa and the U.S. Chamber of Commerce keen to assemble private sector interests towards Africa's hospitality to investment, imagine the creativity that could be applied to the raw entrepreneurial elements in Africa by a team that includes real estate moguls and the founders or former CEOs of some America's largest multinational corporations, leading investment banks, and investment funds.

\section{Prospects for the Future}

Based on experience, one must temper positive assessments for the U.S.-Africa trade relationship with the reality that Africa continues to lag in global trade, integration, and various governance indicators. Indeed, Africa's brightest promise for a strong relationship with the United States may rest outside traditional trade policy. With the number of Africans immigrating from rural areas into more urban areas at rates higher than international migration patterns, Africa's fast rate of urbanization will offer new investment opportunities by narrowing the productivity gap between agriculture and other sectors. Further, UNECA shows that even when formal employment in cities declines, there is a wealth of opportunity in huge, informal labor markets. ${ }^{16}$ Overall, given the world's aging population, Africa's youthful population — its demographic dividend — will underwrite the region's pace of growth. Within the next twenty years, research shows that there will be more working-age Africans than Chinese or Indians.

Coupled with the fast penetration of the Internet and mobile phones, the United States cannot afford to ignore the huge economic opportunities within Africa. At the same time, Africa's growth in 2017 stands at 1.7 percentthe lowest it has been since the start of the century. In UNECA's estimation, Africa needs effective policies to lift growth through increased consumption, investment, and trade. Specifically, on trade, the decline in global demand and commodity prices should inspire Africa to further diversify economically and add value through commoditybased industrialization, raising productivity in agricultural and nonagricultural sectors. Again, AGOA is a lowhanging fruit.

Africa must make the case that if a CFTA were established in 2017 or soon thereafter, this trade regime would potentially lift intra-African trade by 52.3 percent from 2010 to 2022. The United States should support decreasing barriers to intra-African trade, including by urging African states to allow firms to operate their world class supply

\footnotetext{
${ }^{16}$ United Nations Econ. Comm'n for Africa, supra note 3, at 83.
} 
chains and distribution networks without frequent delays and levies at the myriad of customs posts maintained by fifty-five countries. Estimates also find that supportive trade facilitation measures could more than double intraAfrican trade, stimulating industrial products the most. ${ }^{17}$ In this regard, the U.S. private sector and its global logistics companies could play a facilitative role, sponsoring and supporting Africa's weak infrastructure. Such facilitative measures can be implemented through measures undertaken in and between regional economic communities and through multilateral assistance as the WTO's Trade Facilitation Agreement.

If Africa does not play a larger role in redefining this U.S.-Africa trade relationship, U.S. policy for the region will continue to be defined by summits and initiatives of the Corporate Council on Africa or the U.S. Chamber of Commerce, punctuated by modest annual AGOA eligibility country reviews, at which time benefits may be reduced or removed. In addition, with the graduation of countries like Seychelles from the program, all nonLDCs could be removed from AGOA eligibility during the review of the Generalized System of Preferences in 2018.

Ultimately, admitting Africa's traditional cash crops under a revised TRQ regime will not have a deep impact on U.S. farmers or on traditional U.S. business partners such as Brazil. Updating AGOA's rules of origin can only bring success to the program and the development of supply chains- just as adjusting AGOA's third-countryfabric rules enabled Kenya, Lesotho, South Africa, and Ethiopia to achieve some success under AGOA. But the American private sector stands to benefit even more from Africa. The CFTA will create a single market of over a billion people and a collective GDP of over US\$3 trillion. Collaboration among Africa's regional economic communities will accelerate regional projects and unlock the region's trade and industrial development constraints. Combined with urbanization and yet-to-be-optimally-exploited countries such as the Democratic Republic of Congo, the business-centric mind of President Trump may be just the thing that Africa needs to change this trajectory. But first, the onus is on Africa to craft a comprehensive and effective blueprint from which the United States can take the next logical steps.

${ }^{17}$ United Nations Econ. Comm'n for Africa, Economic Report on Africa 2012: Unleashing Africa's Potential as a Pole of Global Growth (2012). 